\title{
Reconsidering the Regional Economic Development Impacts of Higher Education Institutions in the United States
}

\author{
2.1. Higher Education in the United States \\ (online version)
}

\section{Joshua Drucker}

\author{
Department of Urban Planning and Policy \\ University of Illinois at Chicago \\ 412 South Peoria Street \\ Room 211, MC 348 \\ Chicago, IL 60607 \\ tel. 312-413-7597 \\ jdruck@uic.edu
}

(This is the full version of the section. A condensed version is contained in the published volume of Regional Studies.) 


\subsection{Higher Education in the United States}

American higher education is more decentralized than in most other industrialized nations, with systems that differ considerably across jurisdictions (KOEDEL, 2014). Nearly all public institutions are established and controlled by state governments and their instruments. ${ }^{1}$ For private institutions, regulation and oversight varies from state to state as well, though some regulation and much of the substantial influence of financial aid allocation and restrictions originate at the federal level.

The majority of high school graduates in the United States pursue at least some further education (BAUM et al., 2013). Higher education enrollment rates have risen more or less continually since the early 1960s, driven by changes in the educational requirements of well-paying jobs and the widely held view of postsecondary education as a crucial mechanism for social and income mobility. In recent years, however, sharply declining levels of public support and the financial insecurity felt by low- and middle-class families have raised concerns about the accessibility of higher education, particularly regarding increasing gaps in affordability, quality, and prestige among types of institutions (BAUM et al., 2013; PERFETTO, 2012).

Several types of institutions can be distinguished. Universities are full-service teaching and research organizations that typically are active in a wide range of academic and professional disciplines and offer graduate as well as four-year undergraduate (bachelor's) degrees. Liberal arts colleges, in contrast, concentrate chiefly on delivering bachelor's-level education in normal 
academic fields; those offering graduate and professional programs usually do so on a limited basis. Specialized institutions focus on particular subjects (arts, engineering, business, etc.) at either one or both of the undergraduate and graduate levels. There are approximately 2,800 universities and four-year colleges in the United States (Table 1). About one fourth are public, one half are not-for-profit private institutions, and the remainder are for-profit enterprises (NATIONAL SCIENCE FOUNDATION, 2014). Although all types of higher education institutions exist throughout the nation, the northeast portion of the country tends to favor private

Table 1. United States Higher Education Institutions, 2011-2012 Academic Year.

\begin{tabular}{|c|c|c|c|c|c|c|c|c|c|c|}
\hline Institutions & \multicolumn{2}{|c|}{ United States } & \multicolumn{2}{|c|}{ Midwest } & \multicolumn{2}{|c|}{ Northeast } & \multicolumn{2}{|c|}{ South } & \multicolumn{2}{|c|}{ West } \\
\hline TOTAL & 4,588 & & 1,129 & & 963 & & 1,556 & & 940 & \\
\hline public & 1,854 & $40 \%$ & 435 & $39 \%$ & 291 & $30 \%$ & 699 & $45 \%$ & 429 & $46 \%$ \\
\hline not-for-profit & 1,627 & $35 \%$ & 451 & $40 \%$ & 505 & $52 \%$ & 446 & $29 \%$ & 225 & $24 \%$ \\
\hline for-profit & 1,107 & $24 \%$ & 243 & $22 \%$ & 167 & $17 \%$ & 411 & $26 \%$ & 286 & $30 \%$ \\
\hline community college & 1,806 & $39 \%$ & 418 & $37 \%$ & 305 & $32 \%$ & 669 & $43 \%$ & 414 & $44 \%$ \\
\hline liberal arts college & 794 & $17 \%$ & 226 & $20 \%$ & 201 & $21 \%$ & 259 & $17 \%$ & 108 & $11 \%$ \\
\hline university & 1,022 & $22 \%$ & 246 & $22 \%$ & 269 & $28 \%$ & 322 & $21 \%$ & 185 & $20 \%$ \\
\hline specialized & 966 & $21 \%$ & 239 & $21 \%$ & 188 & $20 \%$ & 306 & $20 \%$ & 233 & $25 \%$ \\
\hline $\begin{array}{l}\text { Degrees Awarded } \\
\text { (thousands) }\end{array}$ & United S & tates & Midu & est & Northe & & Sout & & Wes & \\
\hline TOTAL & 7,704 & & 1,822 & & 1,482 & & 2,636 & & 1,764 & \\
\hline public & 5,088 & $66 \%$ & 1,179 & $65 \%$ & 709 & $48 \%$ & 2,005 & $76 \%$ & 1,195 & $68 \%$ \\
\hline not-for-profit & 1,794 & $23 \%$ & 454 & $25 \%$ & 672 & $45 \%$ & 426 & $16 \%$ & 242 & $14 \%$ \\
\hline for-profit & 822 & $11 \%$ & 188 & $10 \%$ & 101 & $7 \%$ & 205 & $8 \%$ & 327 & $19 \%$ \\
\hline community college & 2,489 & $32 \%$ & 543 & $30 \%$ & 304 & $21 \%$ & 1,018 & $39 \%$ & 624 & $35 \%$ \\
\hline liberal arts college & 528 & $7 \%$ & 128 & $7 \%$ & 157 & $11 \%$ & 164 & $6 \%$ & 80 & $5 \%$ \\
\hline university & 4,418 & $57 \%$ & 1,089 & $60 \%$ & 965 & $65 \%$ & 1,376 & $52 \%$ & 987 & $56 \%$ \\
\hline specialized & 269 & $3 \%$ & 61 & $3 \%$ & 56 & $4 \%$ & 78 & $3 \%$ & 72 & $4 \%$ \\
\hline
\end{tabular}

Note: includes only degree-granting institutions.

Regions: The Northeast includes New England and the Atlantic states south to Pennsylvania and New Jersey; the Midwest comprises the Great Lakes and Plains states; the South includes the Atlantic coastal states south from Maryland and Delaware and stretches west through Oklahoma and Texas; the West contains the Rocky Mountains, the Mexican border states west of Texas, the Pacific coast, and Alaska and Hawaii.

Source: National Center for Education Statistics. 
liberal arts colleges and not-for-profit universities, both in terms of prestige and the share of all degrees awarded.

Community colleges, also termed junior or two-year colleges, first were established early in the twentieth century to provide a transition between high school and four-year higher educational institutions and to serve as 'finishing schools' for women (BAUM et al., 2013). In that capacity, they award mainly degrees that can be earned in two or fewer years of full-time study (associate's and pre-associate's degrees). In the 1960s, individual institutions and systems of public community colleges spread widely across the United States in support of making higher education more broadly geographically and financially accessible (AMERICAN ASSOCIATION OF COMMUNITY COLLEGES, 2014). Whereas their pedigree is less prestigious than four-year institutions, the primary aim of community colleges is well-reflected by their appellation: to serve local communities (ECKEL and KING, 2004). Many community college students are engaged in vocational or technical training, retraining to support career changes, or education for recreational or social purposes, such as English instruction for immigrants. Almost all of the more than 1,000 community colleges nationwide are public institutions, there being only a few non-profit examples. The number of for-profit enterprises that focus on vocational and two-year degree programs, however, has expanded rapidly despite considerable turnover, surpassing 600 distinct institutions.

\footnotetext{
${ }^{1}$ The primary exception is the set of national military service academies and graduate institutions.
} 


\section{REFERENCES}

AMERICAN ASSOCIATION OF COMMUNITY COLLEGES (2014) Community Colleges

Past and Present.

BAUM S., KUROSE C. and MCPHERSON M. (2013) An overview of American higher education., The Future of Children 23, 17-39.

ECKEL P. D. and KING J. E. (2004) An overview of higher education in the United States: diversity, access, and the role of the marketplace. American Council on Education, Washington, D.C.

KOEDEL C. (2014) Higher education structure and education outcomes: evidence from the USA., Education Economics 22, 237-56.

NATIONAL SCIENCE FOUNDATION (2014) Science and Engineering Indicators 2014. National Science Foundation, Arlington, Virginia.

PERFETTO G. (2012) Landscape of Higher Education: Net Price, College Board Annual Forum. 